Jurnal Keperawatan Padjadjaran

ISSN 2338-5324 (print)

ISSN 2442-7276 (online)

Online di http://jkp.fkep.unpad.ac.id

DOI : $10.24198 / \mathrm{jkp}$

\title{
Risk Factors of Maternal Nutrition Status During Pregnancy to Stunting in Toddlers Aged 12-59 Months
}

\author{
Hemi Fitriani*, Achmad Setya R, Popy Nurdiana \\ Nursing Science Study Program, Institute of Health Science of Jenderal Achmad Yani, Cimahi, \\ Indonesia \\ Correspondingemail: hemi.ftrn@yahoo.com
}

Submitted: 24-04-2019 Accepted: 22-08-2020 Published: 30-08-2020

\begin{abstract}
Maternal nutrition status during pregnancy highly contributed to risk factors of stunting among children. Bone ossification approximately begins in the sixth weeks of embryonic development and continues to the end of pregnancy. However, inadequate nutrient supply in pregnant women harmed fetal growth. The study aimed to identify the association between pregnant women's nutrition status and stunting. The case-control study using the retrospective design involved mothers with children aged 12-59 months. A proportional random sampling technique was applied to select participants. The sample was 80 toddlers, divided into 40 stunted, and 40 nonstunted toddlers. Data were taken from 27 April to 3 May 2019 through observations following the Mother and Child Health handbook and children's height. Weight gain calculation during pregnancy determined the maternal nutrition status, referred to as maternal pre-pregnancy body mass index. The univariate analysis used frequency distribution, while bivariate analysis used the chi-square test. This study obtained approval from The Health Research Ethics Committee of the Institute of Health Science of General Achmad Yani, Cimahi. The mothers' poor nutritional status caused as many as $85 \%$ of stunted toddlers' prevalence during pregnancy. Results showed that maternal nutritional status during pregnancy was significantly associated with stunting among children (p-value: 0.000 ). The OR value was 13,222 , which means children born to mothers with inadequate nutrient supply during pregnancy were more likely to be stunted as much as 13,222 times, than children born to mothers who had good nutrient supply. It is recommended that health workers prevent stunting from pregnancy by providing supplementary food to pregnant women, and promoting the health of the maternal nutritional status during pregnancy. Suggestions for pregnant women is to increase nutrient intake and nutritional status during pregnancy to prevent stunting in children.
\end{abstract}

Keywords: Case-control, Indonesia, nutrition status, pregnancy, stunting. 


\section{Introduction}

Stunting is a dominant nutritional problem in Indonesia compared to other nutritional issues such as malnutrition, underweight, and overweight, which tends to increase every year. The prevalence of stunting has continued to increase since 2016 to reach $30.8 \%$ in 2018 . This achievement is further from the stunting target tolerated at $20 \%$. West Java Province is one of the provinces with the highest prevalence of stunting in the last three years. In 2017, West Java had a stunting prevalence at the age of 0-59 months of $15.1 \%$ and experienced an increase in 2018 to $31.1 \%$ (Kemenkes RI, 2018). Cimahi City is one of the cities in West Java with a high prevalence of stunting at 0-59 months. The Cimahi City Health Office stated that the incidence of stunting in Cimahi City reached $27.78 \%$ in 2017 . The highest prevalence of stunting, as many as 573 children under five, was in the Central Cigugur Health Center (Kamaludin, 2018).

Stunting has a negative impact both in the short and long term, and can even cause death in children under five years (UNICEF, 2017). Children with stunting will experience physical growth disorders, disruption of brain development, intelligence, and metabolic disorders in the body. Meanwhile, the longterm effects of stunting include low cognitive abilities and learning achievement leading to low economic productivity and decreased immunity. Hence, children get sick quickly and have the risk of developing diabetes, obesity, heart disease, stroke, and disability in old age (Picauly \& Toy, 2013). This condition will be detrimental to individuals and the State.

There are two main factors causing stunting: the mother's condition and factors due to the child's condition (Rahayuwati et al, 2019; Ermiati, Setyawati, A \& emaliyawati, E, 2018). Maternal factors that cause stunting include malnutrition in pregnant women, lack of maternal health during pregnancy, closely spaced pregnancy, and teenage mothers (Budijanto, 2018). While factors due to the child's condition are the intake of exclusive breastfeeding (breast milk), that is not optimal, giving too early MP-ASI, genetic factors, and nutritional deficiencies in children (Dwitama et al, 2018). Besides, a history of infectious diseases is also a risk factor of stunting in children (AM Abd ElMaksou et al., 2017).

Among all these factors, the maternal nutritional status during pregnancy is a crucial causative factor in the first thousand days of life. The pregnant woman's nutrition is the primary source of food for embryonic growth and development, which is the beginning of life (Karinne et al., 2019). Lack of nutrition during pregnancy, which is the beginning of life in the first thousand days of life, where growth occurs very rapidly, is hazardous to stunting in the first two years of life (Black, 2013). Damage during pregnancy cannot be repaired in the next phase of life and will affect health outcomes in childhood and adulthood (Soetjiningsih, 2015). Therefore the nutrition of pregnant women is an essential factor in determining the incidence of stunting.

The formation and growth of the placenta and the rapid development of fetal cells need nutritional intake from the beginning to the end of pregnancy (Alison et al., 2018). At the age of 0 days, nutrients are necessary to prepare the implantation of the conception results, namely the formation of decidua endometrium which contains lots of glycogen, protein, lipids, and minerals, which are sources of embryo nutrition since implantation before the placenta is formed (Guyton \& Hall, 2012). The next stage is the growth and development of the placenta in the first week. The nutritional needs will increase to form a perfect placenta that will guarantee the transportation of oxygen and nutrients from the mother to the fetus and embryo (Alison et al., 2018). Nutritional needs will increase for embryonic and fetal development processes.

Nutrition is essential for the process of growth and bone formation since the beginning of fetal life until the end of pregnancy (Setiawan et al., 2012). At the age of six days, a skeleton is formed, which was initially in the form of cartilage consisting of mesenchyme cells, which are embryonal tissues (Sethi, Priyadarshi, \& Agarwal, 2020). From the age of 6 to 7 weeks, mesenchymal cells undergo an ossification process so that the cartilage will gradually turn into hard bones. Bones will undergo intramembranous 
and endochondral ossification (Alison et al., 2018). Long bones are bones that are responsible for the endochondral ossification process that allows bones to grow longer. This endochondral ossification process occurs in the plate/cartilage epiphyte area, an area at the border of the epiphysis and diaphysis bone (Sethi et al., 2020; Prendergast \& Humphrey, 2014). The endochondral ossification process occurs in the epiphyseal plates that consist of four zones, namely the chondrocyte reserve zone, proliferation zone, maturation zone, and calcification zone, which are cartilages undergoing mineralization (Setiawan et al., 2012; Christiani, Setiawati, \& Yulihastuti, 2017). Besides, each zone has a role.

The rest zone is rich in hyaline cartilage, which consists of ovoid-shaped chondrocytes resting and do not undergo morphological changes. A proliferation zone is a place where chondrocytes are actively mitotic. This process serves as a place for the formation of new chondrocyte cells to replace cells that have undergone hypertrophy and degeneration in parts bordering the diaphysis. This process requires the essential ingredients of protein and energy (Helmita, 2015). New chondrocyte cells formed from mitosis are flat and arranged into columns parallel to the bone's long axis, which results in increased bone length (Setiawan et al., 2012).

The maturation zone is where the chondrocytes are being calcified. This process will produce hydroxyapatite and requires calcium, phosphate, and zinc, helping the absorption of calcium. All necessary minerals must be available in fetal body fluids (Setiawan et al., 2012). In the fourth zone called the calcification zone, the calcification process occurs for the hydroxyapatite deposition to form a thin barrier around degenerated chondrocytes. In this calcification zone, there is one or several layers of chondrocytes which are hypertrophic and dead, so this zone is called the atrophy zone. The calcification process in the calcification zone is very much in need of minerals, calcium, magnesium, and phosphorus, which must be available in the fetal fluid. (Christiani et al., 2017).

The ossification process is closely related to the calcium and phosphorus content of the parent body. Calcium for fetal growth is obtained from the parent through absorption of $\mathrm{Ca} 2+$ from the digestive tract, reabsorption in the proximal tubule of the proximal renal kidney, and reabsorption through osteoclasts (Alison et al., 2018). Inadequate maternal nutritional intake will reduce the supply of nutrients to the fetus so that the fetal nutritional needs are not met (Karinne et al., 2019), resulting in a long growth process on the epiphyseal plate in four inhibited zones (Setiawan et al., 2012). The rate of mitosis in the inhibited proliferation zone will disrupt the process of chondrocyte replacement. If the chondrocyte proliferation rate is not balanced with the chondrocyte resorption rate, then the thickness of the maturation zone will be disrupted. The calcification zone will also decrease as it is related to the previous areas experiencing growth retardation (Setiawan et al., 2012). So that inadequate nutrient intake in pregnant women will reduce the baby's length and high potential.

This study is different from previous studies. The difference is on the measurement indicators of the nutritional status of pregnant women. This study used the calculation of weight gain during pregnancy compared to the Body Mass Index (BMI) before pregnancy. Measurements using BMI are more reliable in reflecting the nutritional status of pregnant women. In previous studies, nutritional status indicators used the Mid Upper Arm Circumference (MUAC) (Sukmawati et al., 2018). This study aimed to identify the relationship of maternal nutritional status during pregnancy with stunting in toddlers aged 12 to 59 months at the Public Health Center (Puskesmas) of Cigugur Tengah.

\section{Method}

The method used an analytic study of a casecontrol with a retrospective design. The population was mothers who had toddlers aged 12 to 59 months who lived in the Cigugur Tengah Health Center's working area. The criteria were, the mother had maternal-andchild health $(\mathrm{MCH})$ card, the mother did not have anemia during pregnancy, and the age of the mother during pregnancy was above 20 years. The criteria determination was to homogenize the population. The $\mathrm{MCH}$ card was a population requirement to get 
Hemi Fitriani: Risk Factors of Maternal Nutrition Status During Pregnancy to Stunting in Toddlers

historical data about the mother's weight and height before pregnancy and weight gain during pregnancy. Data regarding maternal weight before pregnancy, weight at the end of pregnancy and height at pregnancy are secondary data obtained from the $\mathrm{MCH}$ card. These data were needed to determine the history of a mother's nutritional status during pregnancy and to obtain a history of anemia during pregnancy. Based on these requirements, a population of 180 mothers was selected, who were generally newcomers, since Cigugur Tengah includes urban areas. The sample size was obtained using an unpaired categorical formula. According to Dahlan (2010), the basis is the categorical data scale and the unpaired data. The sample obtained was divided into two groups, consisting of 40 non-stunted toddlers and 40 stunted toddlers. The sample was obtained through a proportional random sampling technique because the population spread over several neighborhood groups (Rukun WargaRW). Sampling was carried out in three RWs with a high incidence of stunting. From each RW, the number of samples was obtained based on proportional calculation, from RW 13, 12 stunted, and 12 not-stunted toddlers, from RW 14, 14 stunted, and 14 not-stunted,

and RW 19, 14 stunted, and 14 not- stunted toddlers. The sample determination was conducted randomly in each RW.

The nutritional status was collected from the $\mathrm{MCH}$ handbook to get data on maternal weight before pregnancy and weight gain during pregnancy, Furthermore, the nutritional status of pregnant women was obtained by comparing weight gain during pregnancy with Body Mass Index (BMI) before pregnancy. Data on the stunting of toddlers are collected by measuring toddlers' height using a microtome, and then the toddler's height is compared with the Z-score $(\mathrm{TB} / \mathrm{U})$ table (Kementerian Kesehatan RI, 2018). Data on height and age of children are primary data. Data collection was conducted from 27 April to 3 May 2019. Furthermore, the univariate data were processed with frequency distribution, while the bivariate data used the Chi-square test. The study results were presend in tables. This study received ethical approval from the STIKES Research Ethics Committee general Achmad Yani number 49/KEPK/V/2019.

\section{Results}

Table 1 Frequency Distribution of Maternal Nutritional Status During Pregnancy in the Stunting and Non-Stunting Groups In Cimahi City West Java Province in 2019

\begin{tabular}{lcccc}
\hline \multirow{2}{*}{ Stunted } & \multicolumn{2}{c}{ Stunting } & \multicolumn{2}{c}{ No Stunting } \\
\cline { 2 - 5 } & $\mathbf{n}$ & $\mathbf{\%}$ & $\mathbf{n}$ & $\mathbf{\%}$ \\
\hline Mother with less weight gain & 34 & 85.0 & 12 & 30.0 \\
Mother with normal weight gain and mother with excessive & 6 & 15.0 & 28 & 70.0 \\
weight gain & & & & 100 \\
Total & 40 & 100 & 40 & 100 \\
\hline
\end{tabular}

Table 2 Relationship of Maternal Nutritional Status during Pregnancy with Stunting in Toddlers Age 12-59 Months at Cimahi City West Java Province in 2019

\begin{tabular}{|c|c|c|c|c|c|c|}
\hline \multirow{2}{*}{ Variable } & \multicolumn{2}{|c|}{ Stunting } & \multicolumn{2}{|c|}{ No Stunting } & \multirow{2}{*}{ P Value } & \multirow{2}{*}{$\begin{array}{c}\text { OR } \\
(\mathrm{CI} 95 \%)\end{array}$} \\
\hline & $\mathbf{n}$ & $\%$ & $\mathbf{n}$ & $\%$ & & \\
\hline Mother with less weight gain & 34 & 85.0 & 12 & 30.0 & 0.000 & $13.222(95 \%$ \\
\hline $\begin{array}{l}\text { Mother with normal weight gain and } \\
\text { Mother with excessive weight gain }\end{array}$ & 6 & 15.0 & 28 & 70.0 & & $\begin{array}{c}\text { CI: } 4.400- \\
39.732)\end{array}$ \\
\hline Total & 40 & 100 & 40 & 100 & & \\
\hline
\end{tabular}

Volume 8 Issue 2 August 2020 
The percentage of maternal nutritional status during pregnancy in the stunted and nonstunted groups in Cimahi City, West Java Province in 2019 can be seen in the following Table 1.

Table 1 shows that in the group of stunted toddlers, most of the mother's conditions during pregnancy were in poor nutritional status.

The relationship of maternal nutritional status during pregnancy with stunting in toddlers can be seen in Table 2 below.

Table 2 illustrates the results of the chisquare statistical test with the Continuity Correction test. The p-value was smaller than $\alpha(\alpha=0.05)$, so it could indicate a relationship between the mother's nutritional status during pregnancy and the stunting in toddlers. The statistical test results obtained an Odds Ratio of 13.222 (95\% CI: $4.400-$ 39.732). This means that mothers who gained less weight had a risk for stunting in toddlers by 13 times compared to toddlers whose mothers experienced normal weight gain and mothers with excessive weight gain.

\section{Discussion}

The results found that the majority of stunting toddlers were toddlers born to mothers who were malnourished during their pregnancy. Poor nutritional status in pregnant women is still a significant problem in Indonesia (Kementrian Kesehatan RI, 2018). The level of education, maternal knowledge, and socialeconomic status are the dominant causes (Irianto, 2014; Notifa et al., 2016). This factor is characteristic of urban migrants. Mothers are less able to modify the daily diet with the available income. Mothers' skills in choosing foods require knowledge and awareness of the importance of nutrition during pregnancy. Lack of knowledge and information causes pregnant women to consume food based on what is found and desired, only to overcome hunger without considering the nutritional value.

The study results stated that poor nutritional status during pregnancy risks stunting in children thirteen times compared to mothers with good nutritional status during pregnancy. The results of this study are in accordance with previous studies (Sukmawati et al., 2018; Pusparini et al., 2016). The maternal nutritional status will determine the fulfillment of micro and macronutrient dietary needs during pregnancy for the formation of the placenta, amniotic fluid, organogenesis, and fetal growth and development from the beginning to the end of pregnancy (Black, 2013). Poor nutritional status in pregnant women will result in a reduced supply of nutrients to the fetus, thereby disrupting the fetus's process of organogenesis, growth, and development (Rahmaniar et al., 2011).

The maternal nutritional status determines the process of the formation of an entire placenta. The placenta structure begins with the creation of decidua endometrium starting at the age of 0 days, requiring the essential ingredients of glycogen, proteins, lipids, and minerals (Guyton \& Hall, 2012). These essential ingredients are obtained from the mother; when the mother does not have these nutrient reserves, the formation of decidua endometrium and placenta will be incomplete. An imperfect placenta decreases the supply of oxygen, nutrients, and minerals to the fetus during pregnancy. Fetal life is very dependent on the entire placenta. The supply of blood, oxygen, nutrients, and primary minerals is highly dependent on the placenta because the intestinal and renal fetuses are not functioning (Fikawati et al., 2015; Sethi et al., 2020). Therefore, it takes an entire placenta to ensure the fulfillment of all fetal needs. The entire placenta is formed from the maternal nutritional reserves.

The maternal nutrition status will determine the nutrient reserves needed for fetal organogenesis, including bone organ formation. Human fetal cartilage framework and primary ossification center in the vertebra and long bones are completed in the first trimester (Sethi et al., 2020). The cartilage formation process requires essential protein compounds (amino acid composition), namely collagen, as the dominant structural material in the bone matrix (Guyton \& Hall, 2012). The essential ingredients of collagen bones are obtained from the mother. If the mother cannot fulfill this need, then the formation of fetal cartilage skeleton and primary ossification center in the vertebra and long bones will be inhibited, including 
the potential for reduced bone length. The primary ossification center of the long bones and vertebrae, which is the center of the fetal body's length, has been completed in the first trimester, it can no longer be formed at a later time.

The maternal nutritional status will still guarantee the continuity of the subsequent bone formation process. That is the endochondral ossification process, which allows the bones to grow long, and the intramembranous ossification process helps to harden the bones. The endochondral ossification process of the long bones occurs in the epiphyseal plate, which is the center of fetal length increase. The epiphyseal plate is divided into four zones: the reserve zone, proliferation zone, maturation zone, and mineralization zone. The proliferation zone is a zone where active chondrocyte cells produced new cells by mitosis. This process requires the main ingredients of protein and minerals obtained from the mother. In this condition, also mitochondria of chondrocyte cells need an adequate source of energy for the process of mitosis (Helmita et al., 2015). The mother is the primary source of protein and energy in fetal life through the placenta (Sethi et al., 2020). Lack of energy sources and maternal protein reserves will cause a decrease in the supply of protein and energy to the fetus, thereby inhibiting the mitosis of chondrocyte cells (Helmita et al., 2015). So inhibition of bone cells' formation will cause the thickness of the proliferation zone to decrease. The proliferation zone will affect the next zones, namely the maturation and mineralization zones. It will cause cells shorter in the maturation and mineralization zones, for in those zones, cell proliferations do not occur again (Setiawan et al., 2012; Christiani et al., 2017).

Calcium is an essential nutrient needed in the ossification process in the maturation zone. New cells in the proliferation zone will shift towards the maturation zone. Chondrocyte cells will experience hypertrophy and vacuole; in this zone, there will be no new cell formation (Setiawan et al., 2012). In the maturation zone, chondrocytes play a vital role in the calcification process. Chondrocytes accumulate $\mathrm{Ca}++$ ions in their mitochondria, which then form matrix vesicles. The matrix vesicles will mutually aggregate to form globules that subsequently form hydroxyapatite crystals in the longitudinal septa of the maturation zone. This hydroxyapatite crystal is a material for the process of mineralization and bone calcification in the mineralization zone.

The mother is the primary source of calcium in fetal life through the placenta, which actively moves against electrochemical concentration and gradients. Ca levels of the fetus are maintained from 0.3 to 0.5 $\mathrm{mM} / \mathrm{L}$, higher than Ca levels in maternal serum, to keep the level difference between mother and fetus. Low Ca levels in maternal serum can cause low serum Ca levels in the fetus (Sethi et al., 2020). Low Ca fetal serum causes inhibition of matrix vesicle formation; consequently, it will also inhibit the formation of hydroxyapatite crystals in the longitudinal septa of the maturation zone, which will result in the reduced thickness of the maturation zone.

A lack of zinc intake can also hamper the process of forming hydroxyapatite crystals in the maturation zone. Zinc is instrumental in the absorption of calcium by cells; if zinc levels are low, the uptake of calcium by cells will also be reduced (Setiawan et al., 2012). Zinc also plays a role in the function of growth hormone; if the zinc level is insufficient; then, the growth hormone's role is less than optimal (Black, 2013). Besides affecting bone growth, calcium ions can also affect genetic programs that determine body height. If calcium intake reduces, it will cause low blood calcium levels and may disrupt the genetic height process (Prendergast \& Humphrey, 2014).

Calcium (Ca), phosphorus (Pi), and Magnesium $(\mathrm{Mg})$ are the major minerals in fetal bone mineralization in the mineralized zone. Hydroxyapatite crystals formed in the maturation zone will experience mineralization in the mineralized zone. The fetal $\mathrm{Ca}$ levels are maintained at 0.3 to 0.5 $\mathrm{mM} / \mathrm{L}$ higher than maternal serum levels of $\mathrm{Ca}$. This is to keep differences in levels between mother and fetus. Calcium low levels in maternal serum can cause low levels of serum $\mathrm{Ca}$ in the fetus. Phosphorus is maintained at $0.5 \mathrm{mM} / 1$ higher than maternal serum phosphorus levels. Phosphorus is 
active in the endochondral ossification, which plays a role in the chondrocyte apoptosis process and osteoid formulation. Magnesium is maintained at $0.05 \mathrm{mM} / \mathrm{L}$ higher than maternal serum levels. Mg plays a crucial role in biomacromolecules (DNA, RNA, and Protein), forming an energy-producing bone matrix. Fetal magnesium levels depend on maternal mg intake; if the mother lacks mineral intakes, then fetal serum mineral levels will decrease. Low levels of minerals in fetal serum will inhibit the mineralization process in the mineralized zone, osteoblast dysfunction, and disrupted bone metabolism (Sari et al., 2016). This condition decreases the thickness of the mineralized zone. This in Turn causes the baby's length to be reduced and the potensial for reduced height as well.

Status of mothers with poor nutritional conditions has the potential to reduce fetal height after birth. Mothers who are unable to meet the fetal protein needs will inhibit chondrocyte cell proliferation in the proliferation zone, reducing the thickness of the proliferation zone. Furthermore, mothers who are unable to meet the fetal calcium and zinc needs will cause a decrease in the formation of hydroxy acid crystals in the maturation zone, which ultimately inhibits the process of mineralization and bone calcification in the next area, the cartilage zone. Moreover, mothers who cannot fulfill the fetal serum mineral needs, including $\mathrm{Ca}, \mathrm{Ph}$, and $\mathrm{Mg}$ in the mineralized zone, will cause the thickness of the mineralized zone to decrease. Overall, unmet nutrients cause the thickness of the epiphyseal plate to decrease. The lack of epiphyseal plate thickness will reduce the fetal length and reduce the potential fetal length after birth. So the mother's status during pregnancy has the potential for stunting in children.

This study also found a unique case that stunting could occur in toddlers with mothers who had good nutritional status, even though it happened with a small presentation. The explanation for this unique case can be that the incidence of stunting may be affected by factors other than the nutritional status of pregnant women. Budijanto (2018) states that several factors underlie stunting in toddlers, including the pregnancy spacing that is too close, the teenage mother, the amount of parity, maternal height, and exclusive breastfeeding. In this study, factors of pregnancy spacing, maternal age, and maternal height were not selected. There was a possibility that these factors were the reasons for stunting in mothers with good nutritional status. Based on this, it can be a topic for further research to examine other factors that influence stunting besides the nutritional status of pregnant women.

\section{Conclusion}

The pregnant woman nutritional status is related to the incidence of stunting in toddlers aged 12-59 months. The maternal nutritional status during pregnancy determines the length of the baby and the potential length of the fetus. Recommendations for health workers are to carry out stunting prevention since pregnancy by providing supplementary food to pregnant women and health promotion of the maternal nutritional status during pregnancy. Suggestions for pregnant women are to increase food and nutritional status during pregnancy to prevent stunting in toddlers.

\section{References}

Alison, J. et al. (2018). Formation and growth of the fetus. Encyclopedia of reproduction, 2(3), 370-379. https://doi.org/10.1016/B9780-12-801238-3.64494-X

A.M. Abd El-Maksoud et al. (2017). Evaluation of pro-inflammatory cytokines in nutritionally stunted Egyptian children. Egyptian Pediatric Association Gazette, Elsevier, 65, 80-84. http://dx.doi. org/10.1016/j.epag.2017.04.003

Black, R. E. (2013). Maternal and child nutrition 1: Maternal and child undernutrition and overweight in low-income and middleincome countries. Lancet 382, 427451. http://dx.doi.org/10.1016/S01406736(13)60937-X.

Budijanto, D. (2018). Situasi balita pendek (stunting) di Indonesia. (The situation of 
stunted toddlers in Indonesia). Kementrian Kesehatan RI.

Christiani, R.E., Setyawati, I., \& Yulihastuti D.A. (2017) Morfologi \& perkembangan skeleton fetus tikus (rathus norvegicus) yang diberi ransum mengandung daun kaliandra (callandra calothyrsus) selama kebuntingan. (Morphology \& skeleton development of rat fetus (rathus norvegicus) fed rations containing calliandra leaves (callandra calothyrsus) during pregnancy). Jurnal Biologi, 20(2), 69-74. https://doi. org/10.24843/metamorfosa.2019.v06.i01. p20

Dahlan, M.S. (2010). Besar sampel dan cara pengambilan sampel dalam penelitian kedokteran dan kesehatan (Edisi 3). (Sample size and sampling methods in medical and health research (3rd Edition)). Salemba Medika.

Dwitama et al. (2018). Hubungan pemberian ASI eksklusif dan makanan pendamping ASI terhadap balita pendek usia 2 sampai 5 tahun di Kecamatan Jatinangor. (The relationship between exclusive breastfeeding and complementary feeding for short toddlers aged 2 to 5 years in Jatinangor District). Jurnal Fakultas Kedokteran Universitas Padjadjaran, 3(3), 142-148. http://dx.doi. org/10.24198/jsk.v3i3.16990

Ermiati, Setyawati, A \& emaliyawati, E. (2018). Foot Massage Modification to Reduce blood Pressure in Pregnanat Woman with Preeclampsia. Padjadjaran Nursing Journal, 6(2), 131-138. https://doi.org/10.24198/jkp. v6i2.625

Fikawati, S. et al. (2016). Gizi ibu dan bayi. (Mother and baby nutrition). Rajawali Pers.

Guyton \& Hall. (2012). Fisiologi Kedokteran. (Medical physiology). EGC.

Helmita, R. (2015). Pola distribusi mitokondria sel sel trofoblas blastosis mencit (mus muculus albinus) dan pengaruhnya terhadap kegagalan hatching dan implantasi. (Mitochondrial distribution pattern of blastoblast trophoblast cells of mice (mus musculus albinus) and their effect on hatching and implantation failure). Jurnal Sainstek, VII(1), 16-25. http://dx.doi.org/10.31958/ js.v7i1.121

Irianto, K. (2014). Gizi seimbang dalam kesehatan reproduksi (Balanced nutrition in reproductive health). Alfabeta.

Kamaludin, H. (2018). Ada 7.965 anak yang alami stunting di Kota Cimahi, begini kata dinkes. (There are 7,965 children experiencing stunting in Cimahi City, this is what the health office says). Retrieved October 11, 2019, from https://jabar.tribunnews.com

Karinne, A., C., et al. (2019). Nutrition influence on sow reproductive performance and conceptuses development and survival: A review about L-arginine supplementation. Livestock Science Elsevier, 228, 97-103. https://doi.org/10.1016/j.livsci.2019.08.010

Kementrian Kesehatan RI. (2018). Buku saku pemantauan status gizi 2017. (Nutritional status monitoring pocket book 2017). Kementrian Kesehatan RI.

Nofita, W., et al. (2016). Faktor-faktor yang mempengaruhi status gizi pada ibu hamil di Kabupaten Aceh Besar. (Factors influencing nutritional status of pregnant women in Aceh Besar District). Jurnal Ilmiah Mahasiswa Keperwatan, 1(1).

Picauly, I., \& Toy, S.M. (2013). Analisis determinan dan pengaruh stunting terhadap prestasi belajar anak sekolah di Kupang dan Sumba Timur, NTT. (Analysis of determinants and effects of stunting on school children's learning achievement in Kupang and East Sumba, East Nusa Tenggara). Jurnal Gizi dan Pangan, 8(1). https://doid.org/10.25182/ jpg.2013.8.1.55-62

Pusparini et al. (2016). Indeks massa tubuh rendah pada awal kehamilan dan defisiensi vitamin pada trimester kedua sebagai fakor risiko gangguan pertumbuhan linier pada bayi lahir. (Low body mass index in early pregnancy and vitamin deficiency in the second trimester as risk factors for linear growth disorders in newborns). Jurnal 
Hemi Fitriani: Risk Factors of Maternal Nutrition Status During Pregnancy to Stunting in Toddlers

Gizi Pangan, 11. https://doi.org/10.25182/ jgp.2016.11.3.\%25p

Rahayuwati, L., Nurhidayah, I., Hidayati, N. O., Hendrawati, S., Agustina, H. S., \& Ekawati, R. (2019). Analysis of Factor Affecting Nutrition Status on Children. Jurnal Keperawatan Padjadjaran, 7(2), 119133. https://doi.org/10.24198/jkp.v7i2.1131

Rahmaniar, A.M.B. (2011). Faktor-faktor yang berhubungan dengan kejadian kekurangan energy kronis pada ibu hamil di Puskesmas Tampa Padang Kec. Kaluku Kab. Mamuju Prov. Sulawesi Barat tahun 2011. Tesis Tidak Diterbitkan. [Master's thesis, Universitas Hasanuddin]. Program Pascasarjana Universitas Hasanuddin, Makasar.

Sari, E.M. et al. (2016). Asupan protein, kalsium dan fosfor pada anak stunting dan tidak stunting usia 24-59 bulan. (Intake of protein, calcium and phosphorus in stunted and non-stunted children aged 24-59 months). Jurnal Gizi Klinik Indonesia, 12(4). https:// doi.org/10.22146/ijen.23111

Sethi, A., Priyadarshi, M., \& Agarwal, R. (2020). Mineral and bone physiology in the foetus, preterm and full-term neonates. Seminars in Fetal and Neonatus medicine Elsevier, 25(1). https://doi.org/10.1016/j. siny.2019.101076

Setiawan, A., Sagi, M., Asmara, W., \& Istriyati. (2012). Analisis pertumbuhan kartilago epifisis os tibia fetus mencit (Mus Musculus L) swiss webster setelah induksi ochratoxin a selama periode organogenesisi. (Analysis of the growth of the epiphyseal cartilage of the tibial bone of the swiss webster mice (Mus Musculus L) after induction of ochratoxin a during the period of organogenesis). Jurnal Biologi Papua,4(1), 25-31. https://doi.org/10.22146/ijen.23111

Soetjiningsih. (2015). Tumbuh kembang anak (Edisi 2). (Child development (2nd Edition)). Buku Kedokteran EGC.

Sukmawati, Hendrayati, Chaerunnimah, \& Nurhumaira. (2018). Status gizi ibu saat hamil, berat badan lahir bayi dengan stunting pada balita. (Maternal nutritional status during pregnancy, birth weight of babies with stunting in toddlers). Jurnal Media Gizi Pangan, 25. http://dx.doi.org/10.32382/mgp. v25i1.55

UNICEF. (2017). Undernutrition contributes to nearly half of all deaths in children under 5 and is widespread in Asia and Africa. Retrieved May 16, 2017, from https://data. unicef.org/topic/nutrition/malnutrition/\#. 